\title{
Mammals of Cajuru State Forest and surroundings: a neglected but important Protected Area for the Cerrado conservation in the São Paulo state, Brazil
}

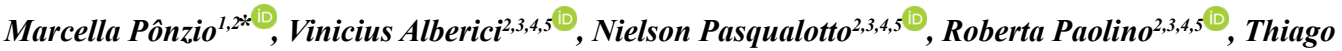 \\ Rodrigues $^{2}$ \& Adriano Chiarello ${ }^{2}(\mathbb{D}$ \\ ${ }^{1}$ Universidade de São Paulo, Instituto de Biociências, Departamento de Zoologia, Grupo de Pesquisa em \\ Ciência da Conservação, São Paulo, SP, Brasil. \\ ${ }^{2}$ Universidade de São Paulo Faculdade de Filosofia Ciências e Letras de Ribeirão Preto, Departamento de \\ Biologia, Laboratório de Ecologia e Conservação, Ribeirão Preto, São Paulo, Brasil. \\ ${ }^{3}$ Universidade de São Paulo, Escola Superior de Agricultura “Luiz de Queiroz”, Piracicaba, SP, Brasil. \\ ${ }^{4}$ Universidade de São Paulo, Centro de Energia Nuclear na Agricultura, Piracicaba, SP, Brasil. \\ ${ }^{5}$ Universidade de São Paulo, Programa Interunidades de Pós-Graduação em Ecologia Aplicada, Piracicaba, SP, BR. \\ *Corresponding author: marcella.cponzio@gmail.com
}

PÔNZIO, M., ALBERICI, V., PASQUALOTTO, N., PAOLINO, R., RODRIGUES, T., CHIARELLO, A. Mammals of Cajuru State Forest and surroundings: a neglected but important Protected Area for the Cerrado conservation in the São Paulo state, Brazil. Biota Neotropica 22(1): e20211262. https://doi.org/10.1590/16760611-BN-2021-1261

\begin{abstract}
The Cerrado has been severely impacted by anthropogenic disturbances, with a tiny proportion of its original extent remaining in its southern portions. In the state of São Paulo, only 7\% of this vegetation remains and relatively little is known about the biodiversity of these fragments. To fill this knowledge gap, we inventoried medium and large-sized terrestrial mammals of a neglected region, including a sustainable use protected area, Cajuru State Forest (CSF), adjacent native vegetation remnants protected by the Native Vegetation Protection Law and owned by a paper and cellulose company (Dois Córregos Farm; DCF), and their surroundings. We recorded 20 native mammal species, five of which are endangered with extinction, including the giant anteater, puma, and maned wolf. We found no significant differences in species richness between CSF and DCF but we found higher estimated species richness for the surrounding areas. Besides encompassing a larger and more heterogeneous area, the surrounding area still has a relatively high proportion $(>30 \%)$ of native vegetation, providing habitat and resources for many species. The estimated mammal species richness for the entire study area was similar to that found in the largest protected area of the Cerrado in São Paulo State, the Jataí Ecological Station and its surroundings. We conclude that our study area still harbors a relatively rich community of large mammals and is important for the conservation of endangered species. This finding is particularly timing since the current State administration is considering to transfer the economic exploitation of CSF to the private sector. We therefore endorse an existing proposal to uplist this protected area, which still lacks a management plan, to a more restricted management category. Besides actions regarding this governmental PA, we argue that it is also important to involve the private sector in a conservation plan for the region.

Keywords: Brazilian Native Vegetation Protection Law; buffer zone; Cajuru State Forest, camera trap; species richness.
\end{abstract}




\title{
Mamíferos da Floresta Estadual de Cajuru e arredores: uma Área Protegida negligenciada mas importante para a conservação do Cerrado no estado de São Paulo, Brasil
}

\begin{abstract}
Resumo: O Cerrado tem sido severamente impactado por distúrbios antrópicos e, especialmente na sua porção sul, poucos são os fragmentos remanescentes desse bioma. No estado de São Paulo, resta aproximadamente $7 \%$ da cobertura original de Cerrado e relativamente pouco se sabe sobre a biodiversidade desses remanescentes. Para preencher essa lacuna, inventariamos mamíferos terrestres de médio e grande porte de uma região pouco estudada que inclui uma Unidade de Conservação (UC) de uso sustentável (Floresta Estadual de Cajuru; CSF), áreas de vegetação nativa protegidos pela Lei de Proteção da Vegetação Nativa e pertencentes a uma empresa de papel e celulose (Fazenda Dois Córregos; DCF), e seus entornos. Registramos 20 espécies de mamíferos nativos, cinco dos quais ameaçados de extinção, incluindo o tamanduábandeira, a onça parda e o lobo-guará. Não encontramos diferenças significativas na riqueza de espécies entre CSF e DCF, mas encontramos maior riqueza estimada de espécies para o entorno. Além de abranger uma área maior e mais heterogênea, essa área ainda apresenta uma proporção relativamente grande (>30\%) de vegetação nativa, fornecendo habitat e recursos para muitas espécies. A estimativa da riqueza de espécies para toda a nossa área de estudo foi semelhante à encontrada na maior UC de Cerrado no Estado de São Paulo, a Estação Ecológica de Jataí e entorno. Concluímos que a área de estudo abriga uma comunidade rica de grandes mamíferos, sendo importante para a conservação de várias espécies ameaçadas de extinção. Essa descoberta é particularmente oportuna, uma vez que o governo estadual está considerando transferir a exploração econômica da CSF para o setor privado. Endossamos, desta forma, uma proposta existente para elevar esta UC, que ainda carece de um plano de manejo, para uma categoria de manejo mais restritiva. Além disso, argumentamos que também é importante envolver a iniciativa privada em um plano de conservação para a região.
\end{abstract}

Palavras-chave: Armadilha fotográfica; Código Florestal; Floresta Estadual de Cajuru; Lei de Proteção a Vegetação Nativa; riqueza de espécies; zona de amortecimento.

\section{Introduction}

In a world increasingly modified by human action, the establishment of governmental protected areas (PAs) is one of the most efficient strategies for biodiversity conservation (Bruner et al. 2001). PAs are part of the territory where land use is restricted, aiming to conserve species, populations, ecosystems, and natural processes. The main function of these areas is to protect threatened elements of biodiversity from processes that compromise their long-term conservation (Margules \& Pressey 2000). However, only $14.8 \%$ of the Earth's surface is covered by PAs (UNEPWCMC \& IUCN 2016), a value below the goal of $17 \%$ proposed by the Aichi Biodiversity Targets for 2020 (CBO 2013). This level of protection is often lower in areas considered hotspots for biodiversity conservation (i.e., with high endemism and high number of threatened species), such as the Atlantic Forest and the Cerrado biomes (Myers et al. 2000, Strassburg et al. 2017, Rezende et al. 2018). Therefore, the conservation afforded by the current network of protected areas has proven to be not sufficient to stop the global biodiversity decline, especially in the highly biodiverse tropical areas (Laurance et al. 2012, Geldmann et al. 2013).

In Brazil, another instrument for the conservation of biodiversity is the Native Vegetation Protection Law (NVPL) (Brancalion et al. 2016), which determines what features and how much of the private lands needs to be set aside for conservation purposes, either as Legal Reserves (LRs) or Areas of Permanent Protection (APPs) (Soares-Filho et al. 2014). The NVPL is an important conservation tool since $53 \%$ of the country's remaining native vegetation is inside private properties. On the other hand, there is still a deficit of more than 11 million hectares that need to be implemented in the form of LRs and many rural owners do not comply with this legislation (Freitas et al. 2017). Nevertheless, the establishment of private protected areas as required by law is fundamental for Brazilian biodiversity conservation and can complement or enhance the benefits promoted by the PAs (Brancalion et al. 2016).
However, both strategies - the creation and management of PAs and the preservation of native vegetation inside private properties - have been insufficient to guarantee the conservation of the second-largest Brazilian domain, the Cerrado (Françoso et al. 2015, Strassburg et al. 2017). This biome contains 4,800 species of endemic plants and vertebrates, supplies three of the largest hydrographic basins in South America, and contributes to $43 \%$ of Brazil's surface waters outside the Amazon (Strassburg et al. 2017). However, only $8 \%$ of the Cerrado is under public governmental protection (Françoso et al. 2015, Strassburg et al. 2017) and just 20\% of any rural property within the Cerrado (outside the Legal Amazon) is required to be protected under LRs - whereas $80 \%$ is required in forested areas in the Amazon (Brancalion et al. 2016). The Cerrado has already lost about half of its original natural cover and it could lose up to $31-34 \%$ of its remaining vegetation by 2050 , leading to the extinction of many endemic species and compromising the functionality of this ecosystem (Strassburg et al. 2017). This scenario is particularly worrying in the São Paulo state, where the Cerrado is reduced to only $7 \%$ of its original coverage (Kronka et al. 2005). Cerrado's remnants in São Paulo state are surrounded by sugar cane, pastures, perennial crops, and urban areas (Durigan et al. 2007), only 6.5\% is protected as PAs and non-compliance with environmental legislation is frequent among local rural owners (Metzger \& Rodrigues 2008, Soares-Filho et al. 2014).

The Cerrado remnants formed by the Cajuru State Forest (CSF), a public governmental PA, and the Dois Córregos Farm (DCF), a private rural property containing APPs and an LR adjacent to CSF, are exceptions to this reality. These areas are located in the northeast region of the São Paulo state and together preserve almost 3,500 ha of native vegetation, mainly composed by open Cerrado formations (savanna and grasslands). The presence of these open formations makes those areas even more relevant for the Cerrado conservation since the closedcanopy vegetation (i.e., "cerradão") has become the predominant native cover of Cerrado remnants in São Paulo state (Durigan \& Ratter 2006). Nevertheless, there is not much information available on these areas, 
the CSF still lacks a management plan, and inventories assessing the diversity of important taxonomic groups, such as medium and largesized mammals, have never been carried out there.

Mammals includes species with different sizes, habitat requirements, and occupied niches, playing several ecological roles and providing relevant ecosystem services (Lacher et al. 2019). Many ecological processes mediated by medium and large-sized mammals have significant effects on the community structure of plants and can alter communities of different trophic levels (Estes et al. 2011, PérezMéndez et al. 2016, Lacher et al. 2019). Despite their importance, medium and large-sized mammals are especially affected by habitat loss and fragmentation (Ceballos \& Ehrlich 2012, Magioli et al. 2021), hunting (Cardillo et al. 2005), and illegal trade (Rosen \& Smith 2010), being among the most vulnerable animal groups to the impacts of the Anthropocene (Dirzo et al. 2014, Tucker et al. 2018).

Hence, we inventoried medium and large-sized terrestrial mammals of the Cajuru State Forest, the Dois Córregos Farm and their surroundings. To better frame the conservation value of these areas, we compared our inventory with a study that used the same sampling approach but was conducted in the largest protected area of the Cerrado in the São Paulo State (the Jataí Ecological Station). Our data is useful for the assessment of the biodiversity of this region and for the development of management strategies for the Cerrado conservation.

\section{Material and Methods}

\section{Study area}

This study was carried out in the Cajuru State Forest (CSF; 2081.4 ha) and in the Dois Córregos Farm (DCF; 2017.2 ha), located in the northeast region of São Paulo state (Figure 1). The predominant climate of the region is defined as equatorial savanna with dry winter (Aw), with precipitation of the driest month below $60 \mathrm{~mm}$ and a monthly mean temperature of the coldest months higher than $18^{\circ} \mathrm{C}$ (Kottek et al. 2006, Beck et al. 2018). The relief of the region is defined as 'Cuestas Balasticas', with low hills (Martinelli 2009, Instituto Florestal 2021).

CSF is a public state-owned protected area of sustainable use, located between the municipalities of Altinópolis and Cajuru (21 ${ }^{\circ} 06^{\prime} 00^{\prime \prime}$ to $21^{\circ} 12^{\prime} 00^{\prime \prime} \mathrm{S}$ and $47^{\circ} 26^{\prime} 00^{\prime \prime}$ to $47^{\circ} 22^{\prime} 00^{\prime}$ " W, datum WGS 84 ). This area is composed mainly of native vegetation $(68,7 \%)$, with the predominance of open Cerrado formations, mostly grasslands (i.e., patches of "campo limpo", "campo sujo" and "campo cerrado", often surrounded by non-native invasive grasses) but also savannas (including flooded wetlands and "cerrado sensu stricto"; Figure 1, Figure 2, Table 1). CSF is also considerably covered by managed forests (31\%), mostly of Pinus spp. plantations (Figure 1, Figure 2, Table 1). This PA does not have a management plan (Durigan et al. 2014, Secretaria de Meio Ambiente, 2020), despite its importance as a groundwater recharge area for the Guarani Aquifer System and one of the last remnants of open Cerrado vegetation of the São Paulo state (Secretaria de Meio Ambiente, 2020). The DCF (Floresta de Alto Valor de Conservação Dois Córregos) is a private rural property owned by Sylvamo do Brasil LTDA. company, encompassing important remnants of native vegetation, protected either as LRs or APPs. DCF is mainly composed of native vegetation $(99.3 \%$ ), with the predominance of open and closed Cerrado formations (Figure 1, Figure 2, Table 1). Both CSF and DCF are surrounded ( $5 \mathrm{~km}$ buffer) by an agro-silvicultural matrix composed of managed forests (27.3\%), which are mainly Eucalyptus spp. plantations, sugar cane $(23.3 \%)$, pastures $(6.7 \%)$ and other less abundant crops, such as orange plantations (Figure 1, Table 1). Summarizing, sampled landscape is composed of a region formed by CSF and DCF where native vegetation predominates (hereafter "interior") and a $5 \mathrm{~km}$ buffer with a higher predominance of anthropogenic land cover types (hereafter "buffer") (Figure 1, Figure 2 and Table 1).

\section{Sampling design and data collection}

We sampled medium and large-sized terrestrial mammals with passive infrared cameras trap (Reconyx, model HC 500), during the dry season (April to September) of 2014. We restricted the sampling to the dry season to have better field conditions and easier access to all sampling sites. This restriction also reduces the interference of different weather conditions (e.g., heat and humidity) on cameras trap performance. We sampled 50 points in total, 24 within CSF $(n=12)$ and DCF $(n=12)$ and 26 within the $5 \mathrm{~km}$ buffer (Figure 1). Each sampling point is defined as one camera trap kept in operation $24 \mathrm{~h} /$ day for approximately 30 days. Cameras trap were fixed to tree trunks at $40-50 \mathrm{~cm}$ above the ground. To distribute our sampling points, we overlaid a regular grid of square cells (1.4 km x $1.4 \mathrm{~km}, 200$ ha each) over our study landscape. The center of each square cell was defined as a potential sampling point. The 200 ha size of the grid was chosen to ensure statistical independence between points, following the mammals' inventory protocol recommended by the Tropical Ecology Assessment and Monitoring Network (TEAM Network, 2011). Then, a similar number of sampling points were randomly allocated within the interior (CSF + DCF) and the $5 \mathrm{~km}$ buffer of our study areas, to equally distribute our sampling effort. In this way, our design enabled a thorough sampling of the study area, maintaining spatial independence among sampling points. Whenever a sampling point fell into sugar cane plantations or pastures, we relocated it to the nearest point with native vegetation, orienting the cameras towards the originally chosen cover class (either sugar cane or pasture). In 24 sampling points, cameras trap were installed in trails or dirt roads. Our total sampling effort was 1593.59 camera.days, with a mean of $31.87 \pm 2.95$ days sampled at each sampling point. To complement camera trapping, we searched for tracks, footprints, and other vestiges (e.g., feces, burrows, and carcasses) of mammals in 200 m-long "transects", i.e., the nearest dirt road/farm track from each camera trap, during the set-up and removal of cameras trap. In total, we walked $20 \mathrm{~km}$ throughout all transects. All vestiges were photographed for further identification with the aid of specific guides (Becker \& Dalponte 1999, Borges \& Tomás 2004, Carvalho Jr. \& Luz 2008, Mamede \& Alho 2008, Moro-Rios et al. 2008, Miranda et al. 2009).

\section{Data analysis and species information}

We analyzed randomized curves of observed species richness (Sest), estimated asymptotic species richness (Chao2) and uniques (i.e., species recorded in only one sampling point) to evaluate sampling sufficiency and compare species richness between: a) the interior (CSF + DCF), the $5 \mathrm{~km}$ buffer and the total area (CSF $+\mathrm{DCF}+5 \mathrm{~km}$ buffer), and b) CSF and DCF separately. We used incidence data (presence/absence) of native species recorded by cameras trap and performed this analysis in the EstimateS software, version 9.1.0 (Colwell 2019). We did not use abundance data because photographic evidence that allow reliably individual distinctions between animals are rare (Choo et al., 2020). 
Pônzio, M. et al.

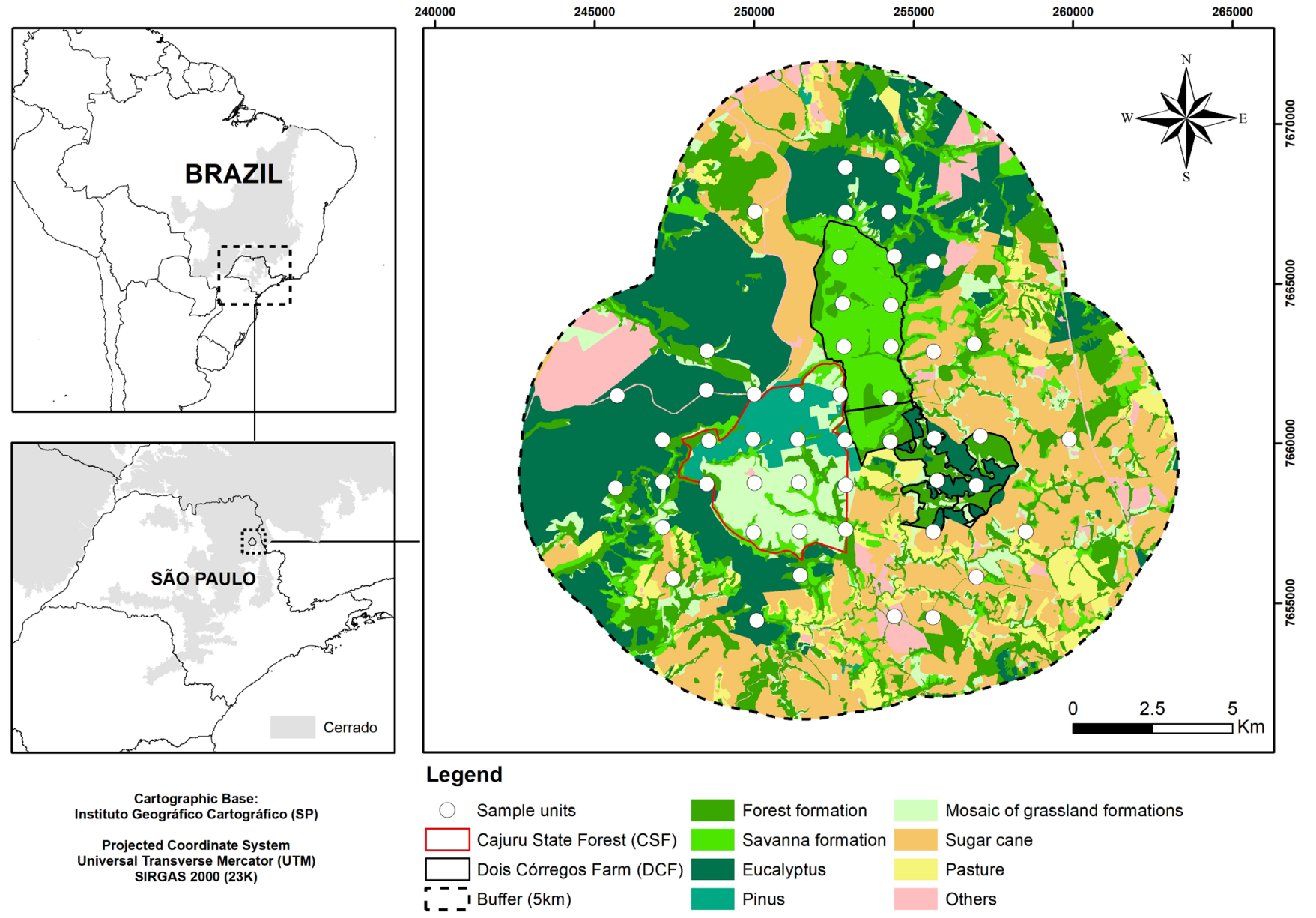

Figure 1. Land use and cover map of Cajuru State Forest (CSF), Dois Córregos Farm (DCF) and a 5 km buffer around these two areas, in the state of São Paulo, Brazil.

Table 1. Land use and cover of Cajuru State Forest (CSF), Dois Córregos Farm (DCF) and its surrounding (5 km buffer), in the state of São Paulo, Brazil.

\begin{tabular}{|c|c|c|c|c|c|c|c|c|}
\hline \multirow{2}{*}{ Land use and cover } & \multicolumn{2}{|c|}{ CSF } & \multicolumn{2}{|c|}{ DCF } & \multicolumn{2}{|c|}{ Buffer } & \multicolumn{2}{|c|}{ Total } \\
\hline & ha & $\%$ & ha & $\%$ & ha & $\%$ & ha & $\%$ \\
\hline Forest formation & 226.5 & 10.9 & 711.0 & 35.2 & 4949.9 & 18.9 & 5887.4 & 19.5 \\
\hline Savanna formation & 216.0 & 10.4 & 1202.1 & 59.6 & 1611.4 & 6.2 & 3029.5 & 10.0 \\
\hline $\begin{array}{l}\text { Mosaic of grassland } \\
\text { formations }\end{array}$ & 985.7 & 47.4 & 90.6 & 4.5 & 1405.4 & 5.4 & 2481.7 & 8.2 \\
\hline $\begin{array}{l}\text { Managed forest } \\
\text { (Eucalyptus) }\end{array}$ & 4.9 & 0.2 & 9.4 & 0.5 & 7503.6 & 28.7 & 7517.9 & 24.9 \\
\hline Managed forest (Pinus) & 642.1 & 30.8 & 0.0 & 0.0 & 76.5 & 0.3 & 718.6 & 2.4 \\
\hline Sugar cane & 0.0 & 0.0 & 0.0 & 0.0 & 7054.1 & 27.0 & 7054.1 & 23.3 \\
\hline Pasture & 0.1 & 0.0 & 1.0 & 0.0 & 1743.4 & 6.7 & 1744.5 & 5.8 \\
\hline Others & 6.2 & 0.3 & 3.2 & 0.2 & 1789.0 & 6.8 & 1798.4 & 5.9 \\
\hline Total & 2081.5 & 100 & 2017.3 & 100 & 26133.3 & 100 & 30232.1 & 100 \\
\hline
\end{tabular}



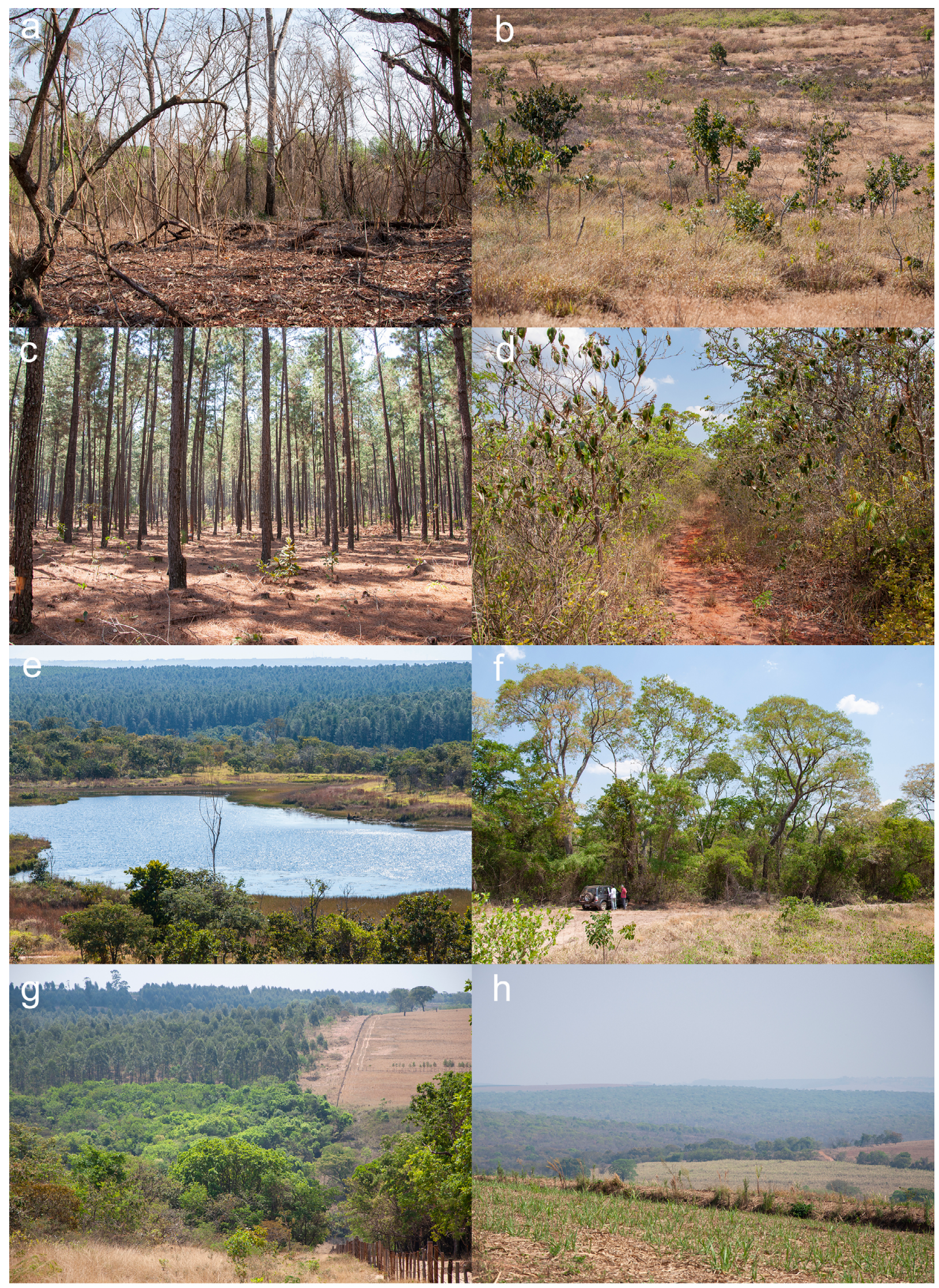

Figure 2. Pictures depicting the study area located in the state of São Paulo, Brazil, characterized by different vegetation types and land uses: deciduous forest (a), cerrado under natural regeneration (b), exotic pine plantation (c), cerrado stricto sensu (d), lacustrine vegetation (e), wooded cerrado or cerradão (f), cropland-planted forest-riverine vegetation transition (g) and sugar cane plantation (h). All photos by A. G. Chiarello. 
We compiled the conservation status of each recorded species based upon international (IUCN, 2020), national (Brazil Red Book of Threatened Species of Fauna; ICMBio, 2018) and state red lists (Decree $\mathrm{N}^{\circ} 63.853$; Assembleia Legislativa do Estado de São Paulo, 2020). We also compared the native species recorded and the richness estimates of this study with the results obtained from similar research conducted in the largest protected Cerrado remnant of the São Paulo state. This area is characterized by a large fragment of native vegetation (including the Jataí Ecological Station - JES, 9013 ha; and the adjacent Luiz Antônio Experimental Station - LAES, 2009 ha), and the surrounding $5 \mathrm{~km}$ buffer (hereafter JES + LAES + buffer $=$ JES landscape). JES and LAES are public governmental PAs and are located less than $50 \mathrm{~km}$ away from our study area (Paolino et al. 2016). The sampling design and data collection in our study and Paolino and collaborators' research followed the same protocol (as described in items 2 and 3 ) and were conducted by the same team of researchers. Paolino and collaborators (2016) sampled 105 points in total, 52 in the interior of the native fragment and 53 within the $5 \mathrm{~km}$ buffer (3150 camera.days) during April-September of 2013. We chose to make a formal comparison only with Paolino and collaborators' research because it was carried out with the same approach used in our study.

\section{Results}

We recorded 20 native species of medium and large-sized terrestrial mammals (seven orders and 14 families), with 15 of them being recorded in the interior (14 in CSF, 10 in DCF) and 19 in the buffer (Table 2, Figure 3). Only one species, the collared-peccary (Dicotyles tajacu), was detected solely by track surveys. Four species found in our study area are threatened with extinction at some level (global, national or state). Among these, the giant anteater(Myrmecophaga tridactyla), puma (Puma concolor), and maned wolf (Chrysocyon brachyurus), are listed as Vulnerable (VU) both at the national and state level (Figure 3). The naked tailed armadillo (Cabassous sp.) was detected by the cameras trap at CSF, but it was not possible to identify it to the species level from the photos. However, one individual of this genus was sighted crossing an internal unpaved road of DCF during a preliminary visit to this area by one of the authors (A. Chiarello). After a quick pursue, this individual was captured, photographed and returned to the same spot minutes later (Figure 3). The shape and size of the ears and the scute patterns in the head of this captured individual clearly indicate it belongs to C. squamicaudis, according to the recent review by Feijó \& Anacleto (2021). Thus, we attest to the presence of this species in the sampled area, but we cannot ascertain that it is the only species of the genus present in our study area. We also recorded five domestic or exotic invasive species, namely: cattle (Bos taurus), European hare (Lepus europaeus), domestic dog (Canis familiaris), domestic cat (Felis catus), and horse (Equus caballus). They were recorded in the buffer, but three of them - cattle, European hare and domestic dog - were also recorded in the interior.

The rarefaction curves of the interior, buffer and total area did not reach asymptotes (Figure 4A), indicating that some additional species remained undetected. Since the $95 \%$ Confidence Intervals (hereafter, CIs) of these three rarefaction curves overlapped, we did not find strong evidence of differences in the observed species richness (Sest) between these areas (Figure 4A). The estimated asymptotic species richness (Chao2) for the interior $(12.24,95 \% \mathrm{CI}=12.01$ to 16.65$)$ was, however, lower than that estimated for the $5 \mathrm{~km}$ buffer $(22.09,95 \% \mathrm{CI}=17.6$ to 47.41$)$, as their $95 \%$ CIs did not overlap at the common number of samples (Figure 4C). Correspondingly, the curve of uniques show a clearly decreasing trend and a lower number of uniques for the interior, while uniques in the buffer did not start to decrease (Figure 4B), indicating a less complete sample for the later region. Analyzing the Sest, uniques, and Chao2 curves for CSF and DCF separately, we observe overlaps between their values, suggesting no significant difference in observed and estimated species richness and a comparable sampling completeness between these two protected areas (Figure 5). Estimated species richness (Chao2) for the CSF was 11.83 ( $95 \% \mathrm{CI}=10.23$ to 24.87$)$ and 13.83 for $\mathrm{DCF}(95 \% \mathrm{CI}=12.23$ to 26.87$)$.

The estimated species richness (Chao2) from camera trap records for our entire study area (CSF + DCF $+5 \mathrm{~km}$ buffer) was very similar (20.18; $95 \% \mathrm{CI}=19.14$ to 29.20 species) to that found for the JES landscape using the same protocol $(21.72,95 \% \mathrm{CI}=19.80$ to 35.84 species; Paolino et al. 2016), comparing the areas at the common number of samples. When comparing the list of recorded species resulting from camera traping and track surveys of our study area with that from JES landscape (Paolino et al. 2016), we noted that only four of 24 species of mammals were not detected in our study area, namely the tapir (Tapirus terrestris), the marsh deer(Blastocerus dichotomus), the capybara (Hydrochoerus hydrochaeris) and the Brazilian guinea pig (Cavia aperea) (Table 3).

\section{Discussion}

The study area harbors a rich community of mammals, with 20 species effectively detected, representing $47 \%$ of all medium and large-sized terrestrial mammal species known for the entire Cerrado (Marinho-Filho et al 2002). This number is probably higher, as our data did not reach the sample sufficiency, the inventory was conducted solely in the dry season, and the estimated richness is up to 29 species ( $95 \% \mathrm{CI}=19.14$ to 29.20$)$. This area seems to be especially relevant to the conservation of the large and vulnerable mammals' species that still survive in the Cerrado of São Paulo state (giant anteater, maned wolf, and puma), as these animals were widely detected. Species richness comparisons between our study area and the JES landscape, interior and buffer, and CSF and DCF lead us to specific considerations, but all results reinforce the ecological relevance of our study area and demonstrate the importance of adequate management measures for the region.

We found very similar values when we compare the estimated richness in our study area with the JES landscape, the largest protected area of the Cerrado of São Paulo state (Paolino et al. 2016). This equivalence might be a consequence of the similar proportion of native vegetation covering both areas $(37.7 \%$ in JES landscape; $38.3 \%$ in our study area) since the large-sized mammal's richness in the Neotropics seems to be most affected by this parameter (Rios et al. 2021). Only four species detected in the JES landscape were not detected in the present study: tapir (Tapirus terrestris), marsh deer (Blastocerus dichotomus), capybara (Hydrochoerus hydrochaeris), and Brazilian guinea pig (Cavia aperea) (Table 3). We advance three possibly explanations for the lack of detection of these species in our study area. First, the presence of some species could be related to the landscape configuration, apart from native vegetation proportion. Contrasting to the overall mammal species (Melo et al. 2017, Rios et al. 2021), the richness of medium and large-sized herbivores seems to be better predicted and negatively affected by the number of patches in the landscape (Rios et al., 2021), and native vegetation are much more fragmented in our study area (9.4 patches/100 ha) than in the JES landscape (2.1 patches/100 ha). This effect may be especially true for those species with a large body size such as the tapir, since our sampled fragments may not be large enough 
Table 2. List of medium and large-sized mammals detected within Cajuru State Forest (CSF), Dois Córregos Farm (DCF) and within their surroundings ( $5 \mathrm{~km}$ buffer), in the state of São Paulo, Brazil. Conservation status according to the global (IUCN, International Union for Conservation of Nature), national (Br, Brazil Red Book of Threatened Species of Fauna) and state (SP, Decree $\mathrm{N}^{\circ} 63.853$ ) level. $\mathrm{C}=$ camera trap record; $\mathrm{T}=$ track survey record; $\mathrm{NL}=$ not listed; $\mathrm{LC}=$ least concern; $\mathrm{VU}=$ vulnerable. Taxonomic classification and nomenclature following Abreu et al. (2021).

\begin{tabular}{|c|c|c|c|c|c|c|}
\hline \multirow[t]{2}{*}{ ORDER/Family/Species } & \multicolumn{3}{|c|}{ Study area } & \multicolumn{3}{|c|}{ Conservation Status } \\
\hline & CSF & DCF & Buffer & IUCN & $\mathrm{Br}$ & SP \\
\hline \multicolumn{7}{|l|}{ DIDELPHIMORPHIA } \\
\hline Didelphis albiventris (Lund, 1840) & & & $\mathrm{C}$ & $\mathrm{LC}$ & NL & NL \\
\hline \multicolumn{7}{|l|}{ CINGULATA } \\
\hline Cabassous sp. & $\mathrm{C}$ & & $\mathrm{C}$ & & & \\
\hline Dasypus novemcinctus (Linnaeus, 1758) & $\mathrm{C}$ & & $\mathrm{C}, \mathrm{T}$ & $\mathrm{LC}$ & NL & NL \\
\hline \multicolumn{7}{|l|}{ Chlamyphoridae } \\
\hline Euphractus sexcinctus (Linnaeus, 1758) & $\mathrm{C}$ & $\mathrm{C}$ & & $\mathrm{LC}$ & NL & NL \\
\hline \multicolumn{7}{|l|}{ PILOSA } \\
\hline \multicolumn{7}{|l|}{ LAGOMORPHA } \\
\hline \multicolumn{7}{|l|}{ Leporidae } \\
\hline Sylvilagus minensis (Thomas, 1901) & $\mathrm{T}$ & $\mathrm{C}, \mathrm{T}$ & $\mathrm{C}$ & NL & NL & NL \\
\hline \multicolumn{7}{|l|}{ RODENTIA } \\
\hline \multicolumn{7}{|l|}{ Dasyproctidae } \\
\hline Dasyprocta azarae (Lichtenstein, 1823) & & $\mathrm{C}, \mathrm{T}$ & $\mathrm{C}, \mathrm{T}$ & $\mathrm{DD}$ & NL & NL \\
\hline \multicolumn{7}{|l|}{ Cuniculidae } \\
\hline Cuniculus paca (Linnaeus, 1766) & & & $\mathrm{C}$ & $\mathrm{LC}$ & NL & NL \\
\hline Cerdocyon thous (Linnaeus, 1766) & $\mathrm{C}, \mathrm{T}$ & $\mathrm{C}, \mathrm{T}$ & $\mathrm{C}, \mathrm{T}$ & $\mathrm{LC}$ & NL & NL \\
\hline Chrysocyon brachyurus (Illiger, 1815) & $\mathrm{C}, \mathrm{T}$ & $\mathrm{C}, \mathrm{T}$ & $\mathrm{C}, \mathrm{T}$ & NT & VU & VU \\
\hline \multicolumn{7}{|l|}{ Procyonidae } \\
\hline Nasua nasua (Linnaeus, 1766) & & & $\mathrm{C}$ & $\mathrm{LC}$ & NL & NL \\
\hline Procyon cancrivorus (Cuvier, 1798) & & & $\mathrm{C}$ & $\mathrm{LC}$ & NL & NL \\
\hline \multicolumn{7}{|l|}{ Mustelidae } \\
\hline Eira barbara (Linnaeus, 1758) & $\mathrm{T}$ & & $\mathrm{C}$ & $\mathrm{LC}$ & NL & NL \\
\hline \multicolumn{7}{|l|}{ Mephitidae } \\
\hline Conepatus semistriatus (Boddaert, 1785) & $\mathrm{C}, \mathrm{T}$ & $\mathrm{C}, \mathrm{T}$ & $\mathrm{C}, \mathrm{T}$ & $\mathrm{LC}$ & NL & NL \\
\hline \multicolumn{7}{|l|}{ ARTIODACTILA } \\
\hline \multicolumn{7}{|l|}{ Cervidae } \\
\hline Mazama gouazoubira (Fischer, 1814) & $\mathrm{C}, \mathrm{T}$ & $\mathrm{C}, \mathrm{T}$ & $\mathrm{C}, \mathrm{T}$ & $\mathrm{LC}$ & NL & NL \\
\hline \multicolumn{7}{|l|}{ Tayassuidae } \\
\hline Dicotyles tajacu (Linnaeus, 1758) & & & $\mathrm{T}$ & $\mathrm{LC}$ & $\mathrm{LC}$ & NL \\
\hline TOTAL & 14 & 10 & 19 & & & \\
\hline
\end{tabular}


Pônzio, M. et al.

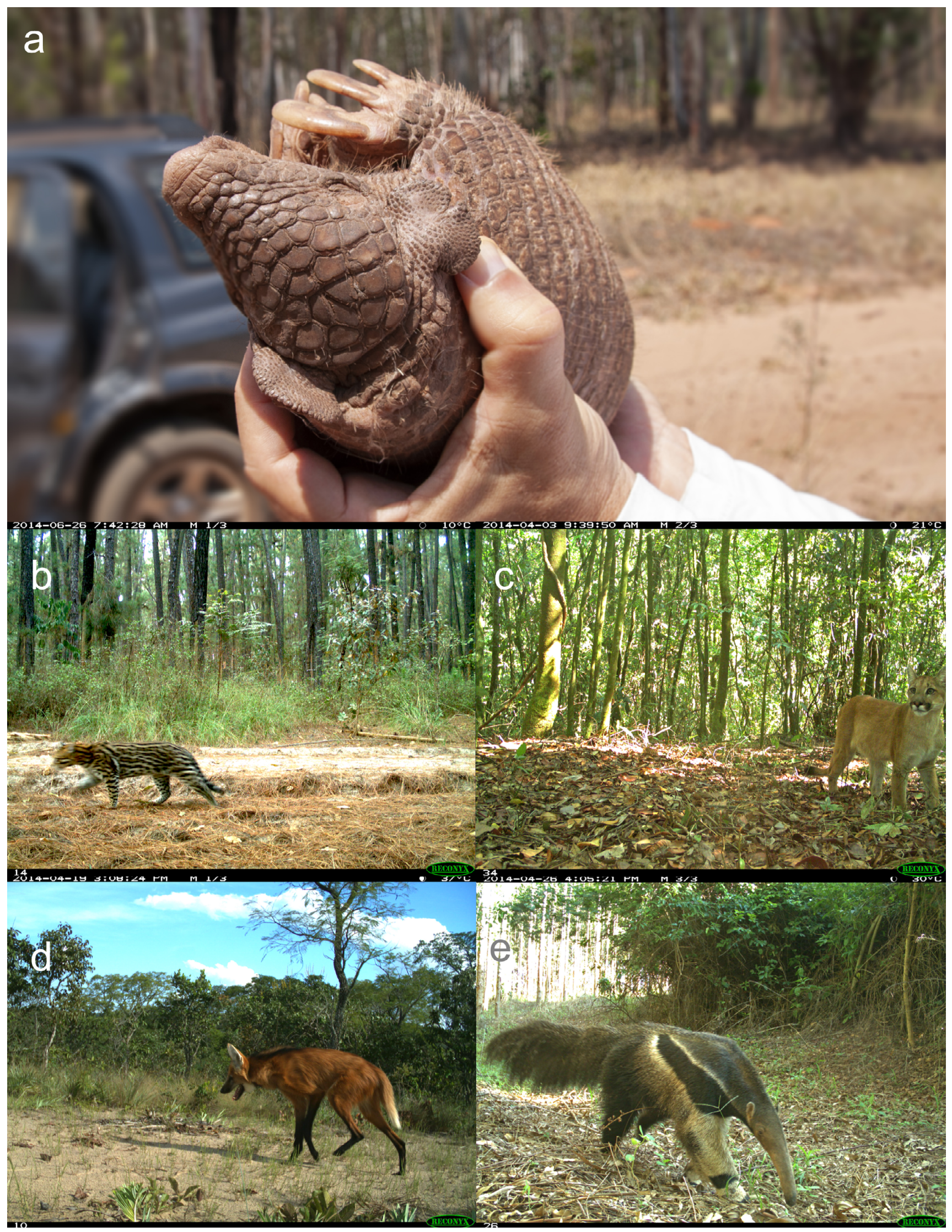

Figure 3. Some species of medium and large-sized terrestrial mammals detected by cameras trap in our study region. a) Cabassous squamicaudis (Lund, 1845) captured and released by A. Chiarello during a preliminary visit in Cajuru State Forest in September 9, 2011. The animal was sighted when it crosses an unpaved road inside CSF at 12:59 $\mathrm{h}$, being photographed and, minutes later, released in the same local inside this protected area. We thank Aurelio Fontes for the company and for holding this animal during the photography; b) Leopardus pardalis (Linnaeus, 1758); c) Puma concolor (Linnaeus, 1771); d) Chrysocyon brachyurus (Illiger, 1815)e) Myrmecophaga tridactyla (Linnaeus, 1758). 

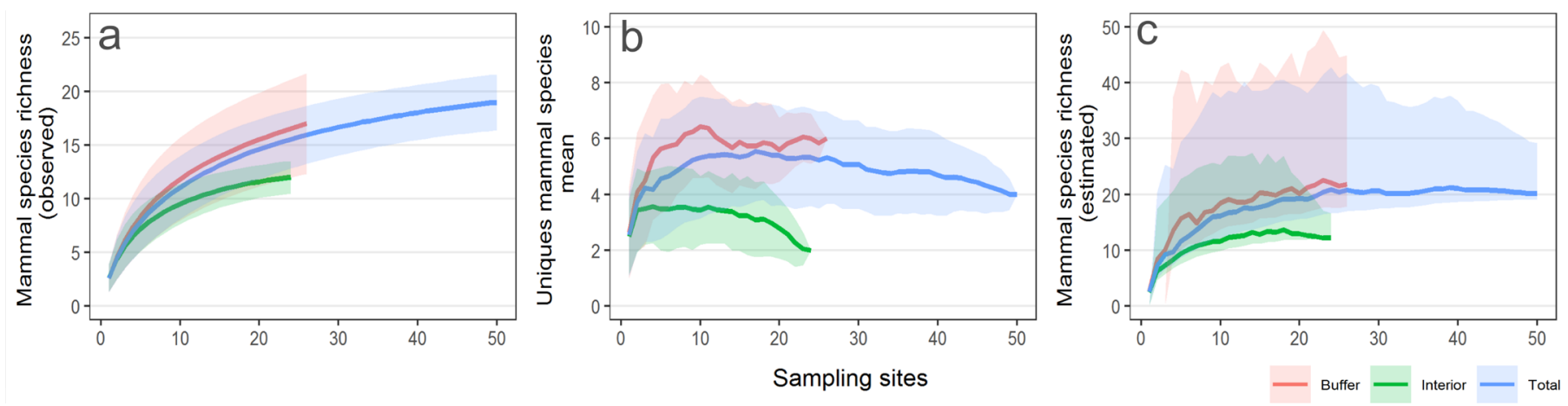

Figure 4. Rarefaction curves for observed richness (a), estimated number of uniques (b) and estimated richness by the Chao2 estimator (c) of native species recorded by camera trapping in the buffer $(5 \mathrm{~km})$, the interior (Cajuru State Forest and Dois Córregos Farm) and the total study area (interior+buffer). Shaded areas are $95 \%$ confidence intervals $(\mathrm{a}, \mathrm{c})$ or standard deviations $(\mathrm{b})$.
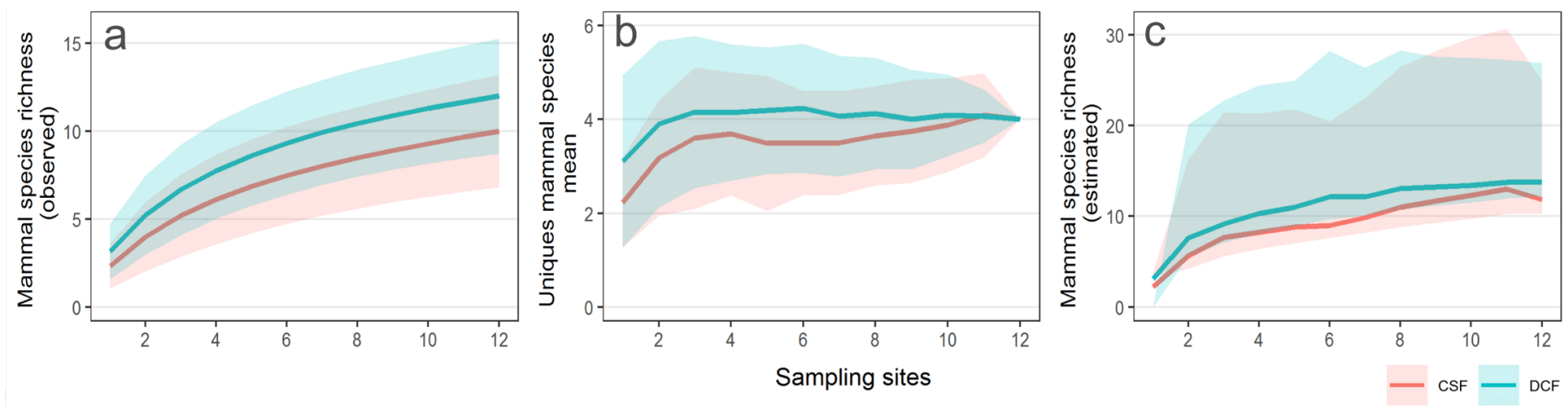

Figure 5. Rarefaction curves for observed richness (a), estimated number of uniques (b) and estimated species richness by the Chao2 estimator (c) of native mammals recorded by camera trapping in Cajuru State Forest (CSF) and Dois Corregos Farm (DCF). Shaded areas are 95\% confidence intervals (a,c) or standard deviations (b).

to sustain a species with large spatial requirements for native vegetation (Medici et al. 2012), even though its current presence in JES could be represented by just one or a few individuals (Rodrigues et al. 2014). Second, the JES landscape has a greater amount of floodplains (2.3 times more than in our study area), which could explain the detection of species that are closely related to aquatic environments, such as the marsh deer - that was recently reintroduced in the JES landscape (Duarte et al. 2012) - and the capybara. Finally, since species as capybara and the Brazilian guinea pig are common and widespread throughout the state of São Paulo (Bressan et al. 2009, IUCN, 2020), a higher sampling effort with more detection methods could result in their detection in our study area. Indeed, other species found in the region could be detected if we had a higher effort, such as Mazama americana, Pseudalopex vetulus, Galictis cuja and Dasypus septemcictus (Fundação Florestal do Estado de São Paulo, 2009). On the whole, the similar species richness found between our study area and the largest remnant of Cerrado of São Paulo state reinforces the importance of CSF-DCF-buffer for the conservation of medium and large-sized mammals, an animal group severely threatened by human activities, but extremely relevant for biodiversity maintenance on a regional scale (Cardillo et al. 2005).

Given the ecological relevance of our study area, we advocate the need for the development of a management plan for Cajuru State Forest. We also endorse the proposal made by Durigan et al. (2014) to recategorize CSF to a more restricted management category, under the name of Cajuru Ecological Station and designating $70 \%$ of its area to scientific research and the conservation of natural ecosystems. The remaining 30\% would be renamed Altinópolis State Forest, aiming for forestry production and the conservation of natural ecosystems. This proposed change is timely and relevant since CSF has been listed as one of the public protected areas of São Paulo state that could potentially be used and exploited by the private sector through concession. Currently, the state law that addresses this question $\left(\mathrm{N}^{\circ} 16.260 / 16,29 / 06 / 2016\right)$ is under embargo by the Public Ministry of the State of São Paulo, which alleges unconstitutionality since there was no consultation either of the management plans or the traditional populations living inside public protected areas (Assembleia Legislativa do Estado de São Paulo, 2020). We argue that the public sector should consider more carefully the ecological relevance of this public-protected area, particularly concerning the recommended change of its current management category (Durigan et al. 2014), to which we fully endorse.

Considering the species richness comparison between interior and buffer, we could expect that the number of species would be greater in the interior, as it has the highest proportion of native vegetation and higher level of legal protection, however, estimated species richness was higher in the buffer (Figure 4C). We argue that this rather unexpected result might be explained by the species-area relationship, as the buffer is more than six times larger than the interior (Table 1) and can be more biodiverse simply because it encompasses a larger area (Arrhenius 1921, Holt et al. 1999). Accordingly, the sample sufficiency was lower for the buffer, which presented a higher number of unique species and no apparent decline in its curve (Figure 4B). In general, the number of singletons tends to decrease as sampling size increases (Coddington et al. 2009) and the same relationship might be expected for uniques. Apart from having a larger area, the buffer also encompasses a greater 
Pônzio, M. et al.

Table 3. Comparison between native medium and large-sized mammal species detected with cameras trap and track surveys in different locations in the Cerrado of São Paulo State, Brazil. The data from our study correspond to sampling points in the interior of Cajuru State Forest (CSF) and Dois Córregos Farm (DCF), and within a 5 km buffer around these two areas. JES = Jataí Ecological Station; LAES = Luiz Antônio Experimental Station and a 5 km buffer, data from Paolino et al. (2016). Taxonomic classification and nomenclature following Abreu et al. (2021). Common names in the region according to Fundação Florestal do Estado de São Paulo (2009).

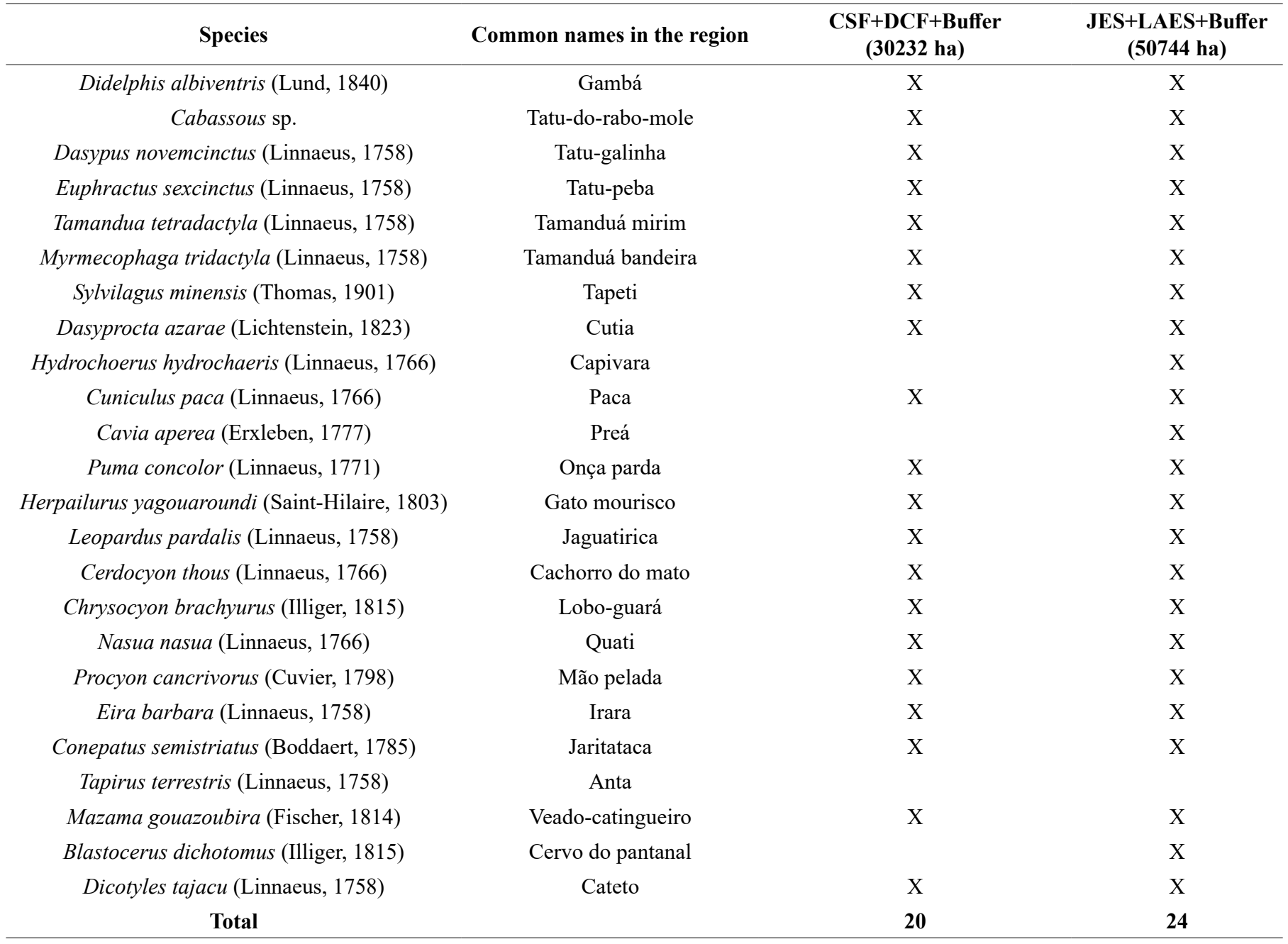

compositional and configurational landscape heterogeneity, when compared to the interior (smaller and more homogeneous) (Figure 1, Table 1). Indeed, heterogeneous areas potentially harbor more species, as they provide greater diversity of resources easier to access (Fahrig et al. 2011). Also, the buffer area still has a relatively high proportion of native vegetation $(>30 \%)$, preserved as APPs or LRs scattered across the agricultural matrix. The presence of interconnected patches of native vegetation in the landscape can facilitate animal dispersion and provide habitat and resources for many species, including large terrestrial mammals (Kremen \& Merenlender 2018). As observed in previous studies, the presence of native vegetation areas is fundamental for large and vulnerable mammals' species living in agroecosystems, such as giant anteaters, maned wolves, and pumas (Coelho et al. 2008, Vynne et al. 2011, Magioli et al. 2014, Azevedo et al. 2020, Versiani et al. 2021). Thus, our result reinforces the importance of buffer zones around PAs and dialogues with other studies that indicate that these areas are used by mammals, especially the larger ones, which need extensive home ranges (Salafsky 1993, Vynne et al. 2011, Massara et al. 2012, Bamford et al. 2014). In this sense, our results also reinforce the high ecological value of heterogeneous agroecosystems that preserve $30 \%$ of the native vegetation and are connected to protected areas.

Regarding the comparison between CSF and DCF, we found both areas having a similar mammal richness. The fact that these areas have almost the same size and are adjacent to each other (Figure 5, Table 2) suggest a similar amount of resources (Arrhenius 1921, Holt et al. 1999) and high animal dispersion between them. This similarity reinforces the importance of private protected areas defined by the NVPL (as DCF) and shows that this type of area can be at least as rich as a PA of sustainable use (as CSF). But more than that, this result reveals that the strategy to connect government and private reserves in agroecosystems can help the landscape to harbor a considerable number of species.

However, compliance with the environmental legislation is generally compromised elsewhere, especially in sugar cane monocultures, the main agricultural crop in the region (Soares-Filho et al. 2014, Brancalion et al. 2016). Due to the association between public and private reserves, our study area has $38 \%$ of native vegetation cover, a percentage close to the minimum threshold (40\%) suggested as necessary for the maintenance of native species in tropical agroecosystems (ArroyoRodríguez et al. 2020), but much higher than the typical pattern of the 
region, characterized by $19 \%$ of native vegetation (Ronquim 2017). The Cerrado of the state of São Paulo stands out nationally as having one of the highest LRs debt and, therefore, a high necessity for vegetation restoration (Freitas et al. 2017, Mello et al. 2021). Although these private native vegetation areas provide ecosystem services that are key for maintaining biodiversity, human well-being, and agricultural production as well, their restoration still generates conflicts with a parcel of rural owners, who do not agree to bear the restoration costs (Metzger et al. 2019, Strassburg et al. 2019). However, a systematic restoration plan can minimize costs and maximize the environmental benefits (Strassburg et al. 2019). By simply adhering to the law, sugar cane producers could increase the provision of ecosystem services, such as carbon sequestration and water purification, while making their products suited for the growing demands of the international market for more sustainable products (Kennedy et al. 2016, Kehoe et al. 2019).

The conservation of the Cerrado in São Paulo state would benefit from a better articulation and dialogue with the private sector. In the absence of natural areas for the establishment of new governmental PAs (Metzger \& Rodrigues 2008), the conservation of the regional biodiversity depends on compliance with environmental legislation and restoration of native vegetation by farmers. Our results demonstrate that we can have a scenario of biodiversity preservation similar to that encompassed by larger and strictly protected nature reserves when APPs and LRs are implemented and connected with existing PAs. Thus, our study highlighted the need to develop a management plan that associates governmental and private reserves while changing rural producers' roles, from the villain of biodiversity to the protagonist of the conservation and restoration of the region.

\section{Associated Editor}

\section{Diego Astúa}

\section{Authors Contributions}

Marcella Pônzio: Conceptualization-Equal, Data curation-Equal, Formal analysis-Lead. Funding acquisition-Equal. InvestigationEqual, Methodology-Lead. Project administration-Equal. ResourcesEqual. Software-Equal. Validation-Equal. Visualization-Equal. Writing - original draft-Lead. Writing - review \& editing-Lead. Vinicius Alberici: Conceptualization-Equal. Data curation-Equal. Formal analysis-Equal. Funding acquisition-Equal. InvestigationEqual. Methodology-Equal. Project administration-Equal. ResourcesEqual. Software-Equal. Validation-Equal. Visualization-Equal. Writing - original draft-Equal. Writing - review \& editing-Equal. Nielson Pasqualotto: Conceptualization-Equal. Data curation-Equal. Formal analysis-Equal. Funding acquisition-Equal. InvestigationEqual. Methodology-Equal. Project administration-Equal. ResourcesEqual. Software-Equal. Validation-Equal. Visualization-Equal. Writing - original draft-Equal. Writing - review \& editing-Equal. Roberta Paolino: Conceptualization-Equal. Data curationEqual. Formal analysis-Equal. Funding acquisition-Equal. Investigation-Equal. Methodology-Equal. Project administrationEqual. Resources-Equal. Software-Equal. ValidationEqual. Visualization-Equal. Writing - review \& editing-Equal. Thiago Rodrigues: Data curation-Equal. Formal analysis-Equal.
Funding acquisition-Equal. Investigation-Equal, Methodology-Equal. Project administration-Equal. Resources-Equal. Software-Equal. Adriano Chiarello: Conceptualization-Lead. Data curation-Equal. Funding acquisition-Lead. Investigation-Equal, Methodology-Equal. Project administration-Lead. Resources-Lead. Supervision-Lead. Validation-Lead. Visualization-Equal. Writing - review \& editing-Lead.

\section{Conflicts of Interest}

The authors declare that they have no conflict of interest related to the publication of this manuscript.

\section{References}

ABREU EF, CASALI DM, GARBINO GST, LIBARDI GS, LORETTO D, LOSS AC, MARMONTEL M, NASCIMENTO MC, OLIVEIRA ML, PAVAN SE, TIRELLI FP. 2021. Lista de Mamíferos do Brasil, versão 2021-1 (Abril). Comitê de Taxonomia da Sociedade Brasileira de Mastozoologia (CT-SBMz). Available in: <https://www.sbmz.org/mamiferos-do-brasil/>. (last access on 14/06/2021)

ARRHENIUS, O. 1921. Species and Area. J. Ecol. 9(1):95-99.

ARROYO-RODRÍGUEZ, V. et al. 2020. Designing optimal human-modified landscapes for forest biodiversity conservation. Ecol. Lett. 23: 1404-1420.

ASSEMBLEIA LEGISLATIVA DO ESTADO DE SÃO PAULO. 2020. Decreto $\mathrm{n}^{\mathrm{o}}$ 63.853, de 27 de novembro de 2018 (last access on 06/10/2020)

AZEVEDO, F.C., LEMOS, F.G., FREITAS-JUNIOR, M.C., ARRAIS, R.C., MORATO, R.G. \& AZEVEDO, F.C.C. 2020. The importance of forests for an apex predator: spatial ecology and habitat selection by pumas in an agroecosystem. Anim. Conserv. 1-11

BAMFORD, A.J., FERROL-SCHULTE, D. \& WATHAN, J. 2014. Human and wildlife usage of a protected area buffer zone in an area of high immigration. Oryx 48(4):504-513.

BECK, H.E., ZIMMERMANN, N.E., MCVICAR, T.R., VERGOPOLAN, N., BERG, A. \& WOOD, E.F. 2018. Present and future köppen-geiger climate classification maps at 1-km resolution. Sci. Data 51-12.

BECKER, M. \& DALPONTE, J.C. 1999. Rastros de mamíferos silvestres brasileiros: um guia de campo. 2 ed., Brasília: Ed. UnB; Ed. IBAMA, DF, Brazil.

BORGES, A.L. \& TOMÁS, W.M. 2004. Guia de rastros e outros vestígios de mamíferos do Pantanal. Corumbá: Embrapa Pantanal, MS, Brazil.

BRANCALION, P.H.S., GARCIA, L.C., LOYOLA, R., RODRIGUES, R.R., PILLAR, V.D. \& LEWINSOHN, T.M. 2016. A critical analysis of the Native Vegetation Protection Law of Brazil (2012): Updates and ongoing initiatives. Nat. e Conserv. 14: 1-15.

BRESSAN, P.M., KIERULFF, M.C.M. \& SUGIEDA, A.M. 2009. Fauna ameaçada de extinção no estado de São Paulo: vertebrados.

BRUNER, A.G., GULLISON, R.E., RICE, R.E. \& DA FONSECA, G.A.B. 2001. Effectiveness of parks in protecting tropical biodiversity. Science.291:125-128.

CARDILLO, M., MACE, G.M., JONES, K.E., BIELBY, J., BININDAEMONDS, O.R.P., SECHREST, W., ORME, C.D.L. \& PURVIS, A. 2005. Evolution: Multiple causes of high extinction risk in large mammal species. Science. 309:1239-1241.

CARVALHO Jr., O. \& LUZ, N.C. 2008. Pegadas: Série boas práticas, v. 3, 64p. Belém: EDUFPA, PA, Brazil.

CBO. 2013. Quick guides to Aichi Biodiversity Targets. Version 2.

CEBALLOS, G. \& EHRLICH, P.R. 2012. Mammal Population Losses and the Extinction Crisis. Science. 296: 904-907.

CHOO, Y.R., KUDAVIDANAGE, E.P., AMARASINGHE, T.R., NIMALRATHNA, T., CHUA, M.A.H. \& WEBB, E.L. 2020. Best practices for reporting individual identification using camera trap photographs. Glob. Ecol. Conserv. 24: 1-9. 
CODDINGTON, J.A., AGNARSSON, I., MILLER, J.A., KUNTNER, M. z \& HORMIGA, G. 2009. Undersampling bias: the null hypothesis for singleton species in tropical arthropod surveys. J. Anim. Ecol. 78: 573-584.

FEIJÓ, A. \& ANACLETO, T.C. 2021. Taxonomic revision of the genus Cabassous McMurtrie, 1831 (Cingulata: Chlamyphoridae), with revalidation of Cabassous squamicaudis (Lund, 1845). Zootaxa 4974(1): 47-78.

COELHO, C.M., DE MELO, L.F.B., SÁBATO, M.A.L., VAZ MAGNI, E.M., HIRSCH, A. \& YOUNG, R.J. 2008. Habitat Use by Wild Maned Wolves (Chrysocyon brachyurus) in a Transition Zone Environment . J. Mammal. 89(1): 97-104.

COLWEL, R.L. 2019. Estimate S: Statistical estimation of species richness and shared species from samples. Version $9.1 \mathrm{http}: / /$ viceroy.eeb.uconn.edu/ estimates/ (last access 06/06/2021)

DIRZO, R., YOUNG, H.S., GALETTI, M., CEBALlOS, G., ISAAC, N.J.B. \& COLLEN, B. 2014. Defaunation in the Anthropocene. Science. 345(6195):401-406.

DUARTE, J.M.B., PIOVEZAN, U., ZANETTI, E. dos S. \& RAMOS, H.G. da C. 2012. Plano de Ação Nacional para a Conservação dos Cervídeos Ameaçados de Extinção.

DURIGAN, G. \& RATTER, J.A. 2006. Successional changes in cerrado and cerrado/forest ecotonal vegetation in western São Paulo State, Brazil, 19622000. Edinburgh J. Bot. 63(1): 119-130.

DURIGAN, G., DE SIQUEIRA, M.F. \& FRANCO, G.A.D.C. 2007. Threats to the Cerrado remnants of the State of São Paulo, Brazil. Sci. Agric. 64(4): 355-363.

DURIGAN, G., ZANCHETTA, A.C.G. de M.A.C.S.Z.D., FACHIN, F. de S.F.H.D.L.H.C., ROBIM, L.C.P.F.M. de J. \& RUFFINO, M.T.Z.T.M.M.B.P.H.P. 2014. Elaboração de procedimentos de manejo e aplicação de recursos oriundos de exploração de produtos e subprodutos florestais, em atendimento ao Projeto de Lei no. 249/2013, que concede o uso da Estação Experimental de Itirapina e da Floresta de Cajuru, por meio de licitação pública. 38p.

ESRI. 2019. Environmental Systems Research Institute, Inc. ArcGIS Professional GIS, v. 10.1 CA.

ESTES, J.A. et al. 2011. Trophic downgrading of planet earth. Science. 333:301-306.

FAHRIG, L., BAUDRY, J., BROTONS, L., BUREL, F.G., CRIST, T.O., FULLER, R.J., SIRAMI, C., SIRIWARDENA, G.M. \& MARTIN, J.L. 2011. Functional landscape heterogeneity and animal biodiversity in agricultural landscapes. Ecol. Lett. 14(2):101-112.

FRANÇOSO, R.D., BRANDÃO, R., NOGUEIRA, C.C., SALMONA, Y.B., MACHADO, R.B. \& COLLI, G.R. 2015. Habitat loss and the effectiveness of protected areas in the Cerrado Biodiversity Hotspot. Nat. e Conserv. 13(1):35-40.

FREITAS, F.L.M. de, SPAROVEK, G., MÖRTBERG, U., SILVEIRA, S., KLUG, I. \& BERNDES, G. 2017. Offsetting legal deficits of native vegetation among Brazilian landholders: Effects on nature protection and socioeconomic development. Land use policy. 68:189-199.

FUNDAÇÃO FLORESTAL DO ESTADO DE SÃO PAULO. 2009. Plano de Manejo do Parque Estadual do Vassununga. 309p.

GELDMANN, J., BARNES, M., COAD, L., CRAIGIE, I.D., HOCKINGS, M. \& BURGESS, N.D. 2013. Effectiveness of terrestrial protected areas in reducing habitat loss and population declines. Biol. Conserv. 161: 230-238.

HOLT, R.D., LAWTON, J.H., POLIS, G.A. \& MARTINEZ, N.D. 1999. Trophic Rank and the Species-Area Relationship. Ecology 80(5):1495.

ICMBIO. 2018. Livro Vermelho da Fauna Brasileira Ameaçada de Extinção.

INSTITUTO FLORESTAL. Cajuru https://www.infraestruturameioambiente. sp.gov.br/institutoflorestal/areas-protegidas/florestas-estaduais/cajuru/ (last access on $02 / 11 / 2021$ )

IUCN. The IUCN red list of threatened species. https://www.iucnredlist.org/ (last access on 11/18/2020)

KEHOE, L., REIS, T., VIRAH-SAWMY, M., BALMFORD, A. \& KUEMMERLE, T. 2019. Make EU trade with Brazil sustainable. Science. 364(6438):341.

KENNEDY, C.M., MITEVA, D.A., BAUMGARTEN, L., HAWTHORNE, P.L., SOCHI, K., POLASKY, S., OAKLEAF, J.R., UHLHORN, E.M. \& KIESECKER, J. 2016. Bigger is better: Improved nature conservation and economic returns from landscape-level mitigation. Sci. Adv. 2: 1-9.
KOTTEK, M., GRIESER, J., BECK, C., BRUNO RUDOLF \& RUBEL, F. 2006. Updated world map of the Köppen-Geiger climate classification. Hydrol. Earth Syst. Sci. 11(5):1633-1644.

KREMEN, C. \& MERENLENDER, A.M. 2018. Landscapes that work for biodiversity and people. Science. 362: 1-9.

KRONKA, F.J.N.. et al. 2005. Inventário florestal da vegetação natural do estado de São Paulo.

LACHER, T.E., DAVIDSON, A.D., FLEMING, T.H., GÓMEZ-RUIZ, E.P., MCCRACKEN, G.F., OWEN-SMITH, N., PERES, C.A. \& VANDER WALL, S.B. 2019. The functional roles of mammals in ecosystems. J. Mammal. 100(3):942-964.

LAURANCE, W.F. et al. 2012. Averting biodiversity collapse in tropical forest protected areas. Nature 489(7415):290-293.

MAGIOLI, M., FERRAZ, K.M.P.M. de B., CHIARELlO, A.G., GALETTI, M., SETZ, E.Z.F., PAGLIA, A.P., ABREGO, N., RIBEIRO, M.C. \& OVASKAINEN, O. 2021. Land-use changes lead to functional loss of terrestrial mammals in a Neotropical rainforest. Perspect. Ecol. Conserv. 19(2):161-170.

MAGIOLI, M., MOREIRA, M.Z., FERRAZ, K.M.B., MIOTTO, R.A., DE CAMARGO, P.B., RODRIGUES, M.G., DA SILVACANHOTO, M.C. \& SETZ, E.F. 2014. Stable isotope evidence of Puma concolor (felidae) feeding patterns in agricultural landscapes in southeastern brazil. Biotropica 46(4):451-460.

MAMEDE, S.B. \& ALHO, C.J.R. 2008. Impressões de cerrado e pantanal. 2a ed. Corumbá, MS, Brazil.

MARGULES, C.R. \& PRESSEY, R.L. 2000. Systematic conservation planning. Nature 405(6783):243-253.

MARINHO-FILHO, J.; RODRIGUEZ, F.H.G.; JUAREZ, K.M. 2002. The Cerrado mammals: diversity, ecology and natural history. In: OLIVEIRA, P.S.; MARQUIS, R.J (Eds.). The cerrados of Brazil. New York: Columbia University Press, 2002.p.266-286.

MARTINELLI, M. Relevo do Estado de São Paulo. Confins Online, 2009 Available in: http://journals.openedition.org/confins/6168. (last access on 22/11/2021).

MASSARA, R.L., PASCHOAL, A.M. de O., HIRSCH, A. \& CHIARELLO, A.G. 2012. Diet and habitat use by maned wolf outside protected areas in eastern Brazil. Trop. Conserv. Sci. 5(3):284-300.

MEDICI, E.P., FLESHER, K., BEISIEGEL, B.D.M. \& KEUROGHLIAN, A. 2012. Avaliação do Risco de Extinção da Anta brasileira Tapirus terrestris Linnaeus, 1758, no Brasil. Biodiversidade Bras. Ano II 3-11.

MELLO, K. de, FENDRICH, A.N., SPAROVEK, G., SIMMONDS, J.S., MARON, M., TAVARES, P.A., BRITES, A.D., RODRIGUES, R.R., JOLY, C.A. \& METZGER, J.P. 2021. Achieving private conservation targets in Brazil through restoration and compensation schemes without impairing productive lands. Environ. Sci. Policy 120:1-10.

MELO, G.L., SPONCHIADO, J., CÁCERES, N.C. \& FAHRIG, L. 2017. Testing the habitat amount hypothesis for South American small mammals. Biol. Conserv. 209:304-314.

METZGER, J.P. and \& RODRIGUES, R.R. 2008. Mapas-síntese. In: Diretrizes para Conservação e Restauração da Biodiversidade no Estado de São Paulo. p.133-145.

METZGER, J.P., BUSTAMANTE, M.M.C., FERREIRA, J., FERNANDES, G.W., LIBRÁN-EMBID, F., PILLAR, V.D., PRIST, P.R., RODRIGUES, R.R., VIEIRA, I.C.G. \& OVERBECK, G.E. 2019. Why Brazil needs its Legal Reserves. Perspect. Ecol. Conserv. 17(3):91-103.

MIRANDA, J.M.D., MORO-RIOS, R., SILVA-PEREIRA, J.E. \& PASSOS, F.C. 2009. Guia ilustrado: Mamíferos da Serra de SãoLuiz do Purunã. Manuais de campo USEB - 12. Pelotas, RS, Brazil.

MORO-RIOS, R.E., SILVA-PEREIRA, J.E., SILVA, P.W.E., MOURA-BRITTO, M. DE, NOGAROLI D. \& PATROCI'NIO, M. 2008. Manual de rastros da Fauna Paranaense. Curitiba: Instituto Ambiental do Paraná . 70 p. 112 il.

MYERS, N., MITTERMEIER, R.A., MITTERMEIER, C.G., DA FONSECA, G.A.B. \& KENT, J. 2000. Biodiversity hotspots for conservation priorities. Nature 403:853-858.

PAOLINO, R.M., VERSIANI, N.F., PASQUALOTTO, N., RODRIGUES, T.F., KREPSCHI, V.G. \& CHIARELLO, A.G. 2016. Buffer zone use by mammals in a Cerrado protected area. Biota Neotrop. 16(2):1-13. 
PÉREZ-MÉNDEZ, N., JORDANO, P., GARCÍA, C. \& VALIDO, A. 2016. The signatures of Anthropocene defaunation: Cascading effects of the seed dispersal collapse. Sci. Rep. 6(24820):1-9.

QGIS Development Team (2019) QGIS Geographic information system.

REZENDE, C.L., SCARANO, F.R., ASSAD, E.D., JOLY, C.A., METZGER, J.P., STRASSBURG, B.B.N., TABARELLI, M., FONSECA, G.A. \& MITTERMEIER, R.A. 2018. From hotspot to hopespot: An opportunity for the Brazilian Atlantic Forest. Perspect. Ecol. Conserv. 16(4):208-214.

RIOS, E., BENCHIMOL, M., DODONOV, P., DE VLEESCHOUWER, K. \& CAZETTA, E. 2021. Testing the habitat amount hypothesis and fragmentation effects for medium- and large-sized mammals in a biodiversity hotspot. Landsc. Ecol. 36(5):1311-1323.

RODRIGUES, T.F., PAOLINO, R.M., VERSIANI, N.F., SALVADOR, N.A.P., OLIVEIRA, E.M. de \& CHIARELLO, A.G. 2014. The lowland tapir (Tapirus terrestris) is back to the largest protected area of Cerrado in the state of São Paulo, Brazil. Tapir Conserv. 23(32):5-9.

RONQUIM, C. C. Uso e ocupação do solo, região nordeste do estado de São Paulo, 2017. Empresa Brasileira de Pesquisa Agropecuária. https://www.embrapa.br/ busca-de-publicacoes/-/publicacao/1084270/uso-e-ocupacao-do-solo- regiaonordeste-do-estado-de-sao-paulo-2017 (last access on 08/26/2020)

ROSEN, G.E. \& SMITH, K.F. 2010. Summarizing the evidence on the international trade in illegal wildlife. Ecohealth 7(1):24-32.

SALAFSKY, N. 1993. Mammalian Use of a Buffer Zone Agroforestry System Bordering Gunung Palung National Park, West Kalimantan, Indonesia. Conserv. Biol. 7(4):928-933.

SECRETARIA DE MEIO AMBIENTE. Ficha resumo de área protegida. https:// www.infraestruturameioambiente.sp.gov.br/institutoflorestal/wpcontent/ uploads/sites/234/2018/09/F-Cajuru.pdf (last access on 11/18/2020)
SOARES-FILHO, B., RAJÃO, R., MACEDO, M., CARNEIRO, A., COSTA, W., COE, M., RODRIGUES, H. \& ALENCAR, A. 2014. Cracking Brazil' Forest Code. Science . 344:363 - 364.

STRASSBURG, B.B.N. et al. 2019. Strategic approaches to restoring ecosystems can triple conservation gains and halve costs. Nat. Ecol. Evol. 3(1):62-70.

STRASSBURG, B.B.N., BROOKS, T., FELTRAN-BARBIERI, R., IRIBARREM, A., CROUZEILLES, R., LOYOLA, R., LATAWIEC, A.E., OLIVEIRA FILHO, F.J.B., DE SCARAMUZZA, C.A.M., SCARANO, F.R., SOARES-FILHO, B. \& BALMFORD, A. 2017. Moment of truth for the Cerrado hotspot. Nat. Ecol. Evol. 1(4):1-3.

TEAM Network. (2011). Terrestrial Vertebrate Protocol Implementation Manual, v. 3.1. Arlington: Tropical Ecology Assessment and Monitoring Network, Conservation Inter- national.

TUCKER, M.A. et al. 2018. Moving in the Anthropocene: Global reductions in terrestrial mammalian movements. Science. 469: 466-469.

UNEP-WCMC \& IUCN 2016. Update on global statistics December 2016. Cambridge, UK and Gland, Switzerland.

VERSIANI, N.F., BAILEY, L.L., PASQUALOTTO, N., RODRIGUES, T.F., PAOLINO, R.M., ALBERICI, V. \& CHIARELLO, A.G. 2021. Protected areas and unpaved roads mediate habitat use of the giant anteater in anthropogenic landscapes. J. Mammal. 102(3): 802-813.

VYNNE, C., KEIM, J.L., MACHADO, R.B., MARINHO-FILHO, J., SILVEIRA, L., GROOM, M.J. \& WASSER, S.K. 2011. Resource selection and its implications for wide-ranging mammals of the Brazilian Cerrado. PLoS One 6(12): 1-12.

Received: $23 / 07 / 2021$

Accepted: 10/02/2022

Published online: 28/02/2022 